\title{
Modes of Timing and Spacing Professional Decisions On the Relationship Between Costing and Caring in Child Protection Work
} Schrøder, Ida

Document Version

Accepted author manuscript

Published in:

Financial Accountability and Management

DOI:

10.1111/faam.12212

Publication date:

2019

License

Unspecified

Citation for published version (APA):

Schrøder, I. (2019). Modes of Timing and Spacing Professional Decisions: On the Relationship Between Costing and Caring in Child Protection Work. Financial Accountability and Management, 35(4), 319-336.

https://doi.org/10.1111/faam.12212

Link to publication in CBS Research Portal

\section{General rights}

Copyright and moral rights for the publications made accessible in the public portal are retained by the authors and/or other copyright owners and it is a condition of accessing publications that users recognise and abide by the legal requirements associated with these rights.

Take down policy

If you believe that this document breaches copyright please contact us (research.lib@cbs.dk) providing details, and we will remove access to the work immediately and investigate your claim. 


\section{Modes of Timing and Spacing Professional Decisions: On the Relationship Between Costing and Caring in Child Protection Work}

Ida Schroder

Journal article (Accepted manuscript*)

\section{Please cite this article as:}

Schrøder, I. (2019). Modes of Timing and Spacing Professional Decisions: On the Relationship Between Costing and Caring in Child Protection Work. Financial Accountability and Management, 35(4), 319-336. https://doi.org/10.11l1/faam.12212

This is the peer reviewed version of the article, which has been published in final form at DOI: https://doi.org/10.1111/faam.12212

This article may be used for non-commercial purposes in accordance with Wiley Terms and Conditions for Self-Archiving

* This version of the article has been accepted for publication and undergone full peer review but has not been through the copyediting, typesetting, pagination and proofreading process, which may lead to differences between this version and the publisher's final version AKA Version of Record. 


\title{
Modes of timing and spacing professional decisions: On the relationship between costing and caring in child protection work
}

\author{
Ida Schrøder \\ Department of Operations Management, \\ Copenhagen Business School, Frederiksberg, \\ Denmark \\ Correspondence \\ Ida Schrøder, Department of Operations Management, \\ Copenhagen Business School, Solbjerg \\ Plads 3,B402, Frederiksberg 2000, Denmark. \\ Email: idsc@kp.dk \\ Funding information \\ Danish National Board of Social Services; \\ Independent Research Fund Denmark Research, \\ Grant/Award Number: 1329-00137B

\section{ORCID} \\ Ida Schrøder https://orcid.org/0000-0003-1358-6007
}

How to cite this article: Schrøder I. (2019). Modes of timing and spacing professional decisions: On the relationship between costing and caring in child protection work. Financial Accountability \& Management. 35:319-336.

https://doi.org/10.1111/faam.12212

\begin{abstract}
Within public sector accounting research, the question of how "costing" is implemented and how it transforms professional "caring" work has been widely studied and debated. Studies have, for instance, pointed to contextual variables that make cost information more or less useful in professional decision making. However, in doing so, scholars also assume that decision making follows a linear path that can be informed and transformed by cost information. In this paper, I take it as my starting point that both costing and caring vary as they are combined in professional decisionmaking processes. I use the broad and processual definition of calculation from the work of Callon and Muniesa to analyze how distinctions about vulnerable children's situations are made relevant for the choice and delimitation of social services. This allows me to investigate how, when, and where distinctions between costing and caring are drawn rather than assuming that costing and caring are preexisting and stable practices that can be put to use or not.
\end{abstract}

\section{Keywords}

actor-network theory, caring, costing, professional decisions, social services, spacing, timing

\section{INTRODUCTION}

The ambition of this paper is to investigate the relationship between "costing" and "caring" in the allocation of social services to individual children in need. This concerns children and young people who have been neglected, maltreated, and sexually or physically abused. And it concerns children and young people who, for reasons such as poverty, mental issues, or lack of parental abilities, are not developing, or are at risk of not developing, like their peers. Deciding how to intervene in the lives of children and their families is an ambiguous and meticulous process with far-reaching consequences for the individual child and family as well as for public budgets. Interventions range in scope and scale from a few hours of pedagogical guidance at home with the family to 24-h treatment of the child in an out-of-home facility. In Denmark,37\% of children received social services in 2017 and this amounted to costs ofEUR2.5 billion (DKK 18.2 billion). This is one third of the annual national budget for all social services. By way of comparison, this is only $25 \%$ less than the total Danish day-care expenditure for all children excluding those with special needs (Statistics Denmark, 
2018). The costs for social services are allocated on a daily basis by social work professionals in the child protection departments of local governments. In this paper, I unfold how information about the costs of services are part of their decision making.

From public sector accounting research (PSAR) in the area of health and social care, we know that professional decisions concerning clinical treatment and social services have been transformed since the introduction of costing systems and decentralized budget responsibility (Abernethy, Chua, Grafton, \& Mahama, 2007; Bracci \& Llewellyn, 2012; Chapman, Kern, \& Laguecir, 2014; Frandsen, 2010; Jönsson \& Solli, 1993; Kurunmäki, 2004; Llewellyn, 1993, 1998a; Llewellyn \& Northcott, 2005; Pettersen \& Solstad, 2014; Sjögren \& Fernler, 2019). This research traces a historical trend toward increased collaboration between accounting systems and professional judgment to a degree where it is no longer possible to separate the two (Kurunmäki, 2004; Pettersen \& Solstad, 2014; Sjögren \& Fernler, 2019). Only a few studies, however, have set out to investigate the involvement of costing in decision-making processes in regard to individual clients and patients (Bracci \& Llewellyn, 2012; Frandsen, 2010; Sjögren \& Fernler, 2019). Bracci and Llewellyn (2012) argue that the degree of complexity in the clients' problems influence the costing practices, and Frandsen (2010) argues that costing numbers are translated into the clients' disease, and Sjögren and Fernler (2019) suggest that costs are translated into entities of time. In this way, the papers suggest that calculative practices are distributed into a broad variety of activities that make it possible to translate accounting into the domain of caring, and caring into the domain of accounting. However, there is also the possibility that the relationship between costing and caring varies according to the practical decision-making processes rather than just being a matter of translating the one into the other.

This paper is motivated by the question of how cost information comes to be involved in professional decision making regarding individual clients and citizens. It extends the research on calculative practices as distributed into a broad variety of activities by opening up the notions of both costing and caring and by studying them from the inside. In doing so, I suggest that costing and caring emerge as the consequence of practical and calculative capabilities rather than being inherently opposed and distinct practices. Accordingly, the research question I ask is how, when, and where distinctions between costing and caring are drawn. This contributes to the debate on the relationship between costing and caring by making a movement from looking for costing as an input and/or outcome of decision making (cf. Abernethy et al., 2007; Abernethy \& Stoelwinder, 1995; Arnaboldi, Lapsley, \& Steccolini, 2015; Bracci, 2014; Bracci \& Llewellyn, 2012; Carlsson-Wall, Kraus, Lund \& Sjögren, 2016; Chapman et al., 2014; Glennerster, 1994; Kraus, 2012; Kraus \& Lindholm, 2010; Kurunmäki, 1999, 2004; Kurunmäki, Lapsley, \&Melia, 2003; Laughlin, 1996; Llewellyn, 1993, 1998a; Llewellyn \& Northcott, 2005; Llewellyn \& Saunders, 1998; Mannion \& Smith, 1997; Nyland \& Pettersen, 2004; Pettersen \& Solstad, 2014) toward investigating how, when, and where the relationship between costing and caring emerges throughout decision-making processes. This contribution is important, because it brings nuance to our understanding of the relationship between costing and caring and it allows for an analysis of how variances in the use of cost information occur.

In order to answer the research question, I employ the broad and processual notion of calculation as proposed by Callon and Muniesa (2005). I use this as an approach to analyze how, when, and where distinctions are drawn about the situation of a child and made relevant for the choice and delimitation of child protection services. This allows me to treat cost information on the same terms as needs information. In this way, I let the empirical material unfold how the relationship between costs and needs emerge. The analysis is based on a qualitative study of professional decision making in the child protection departments of three Danish local governments. I identify three modes of timing and spacing professional decisions, each of which constitutes a specific relationship between costing and caring: (1) protecting, (2) maintaining, and (3) preventing. These modes of timing and spacing professional decisions contribute to PSAR by offering a categorization of the varied ways in which professional decisions are organized to take both individual needs and information about costs into account.

The remainder of the paper is organized as follows. First, I review the findings and arguments about the relationships between costing, curing, and caring in PSAR. I then present the theoretical approach used in the paper. This is followed by a section on the methodological considerations involved in the design and analysis of the collected material. In the subsequent empirical account I analyze how the modes of timing and spacing professional decisions unfold in three distinct modes. Finally, I discuss how the three modes contribute to PSAR and conclude with the theoretical implications.

\section{COSTING, CURING, AND CARING IN HEALTH AND SOCIAL CARE SETTINGS}


Gaining control of costs in public sector human service areas has been an aim of the pervasive new public management reforms since the 1980s (Hood, 1991). To this end, accounting has been used as a tool to standardize professional judgment in service areas such as health and social care, where welfare professionals decide what services to provide to individual citizens (Abernethy et al., 2007; Lapsley, 2008; Van Helden, 2005). This has spurred a research interest into "how accounting systems can shape and form the possibilities for action within organizations" (Kurunmäki, 2009, p. 1373). Even though this question concerns all public human service areas, the vast majority of PSAR focuses on accounting in healthcare (Van Helden, 2005). Specific budgeting models (Johansson \& Siverbo, 2014; Modell \& Lee, 2001; Nyland \& Pettersen, 2004; Pettersen, 1995), enhanced and decentralized budget responsibility (Jacobs, 2005; Kurunmäki, 2004; Kurunmäki et al., 2003), as well as new costing systems (Chapman et al., 2014; Llewellyn \& Northcott, 2005), have all been studied as a means to learn about the various roles and effects of accounting technologies in healthcare settings.

These studies draw different conclusions about the role of accounting. But they generally assume that costs can be calculated in ways that - to some extent-reflect the choices made by medical professionals. Based on this, they set out to investigate details regarding the use and consequences of specific accounting technologies. An illustrative example of this is Llewellyn and Northcott's (2005) study of how healthcare activities "become average." They describe how the Healthcare Resource Group costing system classifies "dissimilar patients, diseases and diagnosis into a single category (or product) through a focus on the resource implications of the procedures that are related to clinical diagnosis" (Llewellyn \& Northcott, 2005, p. 562, italics added). This reflects a process of decision making, where the choice of procedure (cure) is made after diagnosing the disease or injury and accordingly that cost information refers back to the implication of choosing the one or other procedure. In this way, cost calculations are delimited as something that is made in advance and put to work as guiding standards for the professional choices of cure. It is this, delimited, role of cost calculations that enables Llewellyn and Northcott (2005) to argue that costs decrease when individual professional decision making is transformed into a more cost-based way of deciding how to allocate resources.

Just like costing is often conceived to be a standardizing mechanism, so professional decisions are conceived to be an individualizing mechanism. This dichotomous relationship has fostered research into the problematic relationship between "costing" and "curing." Research has shown the complexities involved in the processes of transforming professional decisions about the choices of cure into cost-based, standardized decisions. Sometimes the medical professionals resist taking cost information into account (Jacobs, 2005; Kastberg \& Siverbo, 2016; Kurunmäki et al., 2003). They might "game" the information by adjusting registrations to enhance funding (Lægreid \& Neby, 2016). The cost information might produce distorted images of curing activities (Briers\&Chua, 2001; Covaleski, Dirsmith,\&Michelman, 1993; Modell \& Lee, 2001; Preston, Cooper, \& Coombs, 1992) and leave the patient black-boxed as a number of diagnoses in an electronic information system (Vikkelsøe, 2007). These studies forcefully illustrate that there is not one, but numerous ways to investigate and explain the role of "costing" in "curing" settings. Nevertheless, the studies generally take as their point of departure that cost calculations are made a priori as a means to guide and standardize the professional choice of curative procedure. Subsequently, they take an interest in investigating whether, or to what extent, "curing" is possible under the conditions of a specific "costing" technology.

Studies of the roles and effects of management accounting in social services illustrate that other kinds of relations are also at play (Wällstedt, 2015). Earlier studies from the 1990s, aswell asmore recent studies, illustrate that cost allocation is based on relations that breach the realm of the public sector accounting system: Trust in the supplier of social care, for instance, has been argued to be more important than the price of the care services (Mannion \& Smith, 1997). Whether a client's problems are intractable or not have been found to influence the social worker's financial accountability (Bracci \& Llewellyn, 2012). Several argue that the use of cost information is socially determined (CarlssonWall et al., 2016; Jönsson \& Solli, 1993; Llewellyn, 1998b). And sometimes the practice of allocating costs is not even in the hands of the local government, but in the hands of private citizens who have been given a personalized budget (Bracci, 2014; Junne \& Huber 2014). Together, these studies all forcefully illustrate that professional decision making in public human service organizations does not always follow a linear process.

Quite the contrary. Rather than decide which "cure" to choose, it could be said that social workers decide, more broadly, how to "care" for the client (Llewellyn, 1998a) by moving back and forth between identifying a social problem and choosing a possible solution. In this way, a decision about the choice of a service (a "treatment") is as much about assessing, and defining, what the problem is, as it is about choosing between alternative solutions on how to help. This nonlinear process is reflected in the means of calculating the costs of services, in the sense that standard costs do not provide any information about the links between intervention and implications (Bracci \& Llewellyn, 2012). Rather than 
being based on the goals and expected outcome of the services, costs are calculated based on how much time the social and careworkers spent on the social service (Carlsson-Wall et al., 2016; Kraus \& Lindholm, 2010; Llewellyn, 1993). This means that the cost information does not reflect the resource implications that follow from the assessment of needs (cf. Llewellyn \& Northcott, 2005) but simply the costs of operating particular social care services. Accordingly, and in contrast with what is found in the area of health care, the costs implication of needs must necessarily be compiled during and after the professional assessment of the client's problems and the choice of service.

This is the reason why this paper takes as its point of departure that the relationship between costing and caring emerges throughout the process of professional decision making. Rather than investigating whether or not "caring" and "curing" is possible under the conditions of a specific accounting technology (Bracci, 2014; Kraus, 2012; Llewellyn, 1998a; Llewellyn \& Northcott, 2005; Pettersen \& Solstad, 2014), this paper opens up the notion of costing, and investigates how, when, and where costing comes to be involved in such a nonlinear "caring" process. In this way, it is an "inside-out view" rather than a discussion of how a certain context influences the act of making decisions (cf. Bracci $\&$ Llewellyn, 2012; Kraus \& Lindholm, 2010).

\section{THEORETICAL APPROACH: MODES OF TIMING AND SPACING PROFESSIONAL DECISIONS}

In line with constructivist accounting literature I view accounting as a fluid practice which is involved in, and constituted by, the socio material networks that it is a part of (Baxter \& Chua, 2003; Justesen \& Mouritsen, 2011; Mouritsen, Mahama, \& Chua, 2010). This means that I view costing as well as caring as dispersed across time and space in the myriad elements that make up decision-making processes (Czarniawska, 2004). A professional decision then is the result of a process of organizing information in a way that makes it possible to choose between alternative courses of action. As a means to unfold how different relationships between costing and caring are produced in this process, I draw inspiration from the broad and processual view of calculations as proposed by Callon and Muniesa (2005). In their view, a calculation is not only the result of a process. Rather, calculation is a process. It is a process where difficult definable situations (or in their words "goods") are delimited by attributing them with properties that produce distinctions (p. 1231, 1235). In this way, their approach allows me to stay attuned to the practical work of producing distinctions. This makes it possible to analyze decisions as practices rather than retrospective accounts.

As suggested by Callon and Muniesa (2005, p. 1231), I analyze decisions as a three-step process consisting of arranging information, associating elements, and achieving a result. This division of the process adds a nuance to the process of decision making that gives me more places to look for costing and caring than if I had concentrated on analyzing the outcome of decision making. The three steps are neither exhaustive, nor practically separable, but serve as a means to describe the process of reaching decisions. The first step is a process of arranging information related to the situation at stake. In this process, distinctions are drawn between what to include and exclude by imagining and estimating which courses of action to take. In order to describe how this practically takes place, I employ timing and spacing as concepts to trace how, when, and where distinctions are made. I view timing as an act of turning situations and information into a temporal order, and spacing as an act of bringing information from one place to another (Czarniawska, 2004). However, in the second step of the process different timings and spacings are produced as a result of the way that information is mobilized to make associations between the problem and its solution (Quattrone \&Hopper, 2005). So timing and spacing work in two ways: timing and spacing organize the manner in which distinctions are drawn, and timings and spacings (in plural) are results produced by these distinctions (Jones, McLean, \& Quattrone, 2004; Kirk \& Mouritsen, 1996). The first and the second steps bring to the foreground the practical efforts that make it possible to act on the situation and move toward a choice of service. In the third step, the final distinctions about the situation at stake and the choice of service are achieved. This step links together the included information and extracts a result-a choice-that was already being prefigured during the preceding steps of the decision.

In line with the symmetrical approach of ANT (Czarniawska, 2017; Justesen \& Mouritsen, 2011; Latour 2005) I attend to the detailed and practical work of timing and spacing information into a choice of service. Through this lens, calculations as well as judgments are means of transforming heterogeneous elements such as spreadsheets, meeting rooms, assessment reports, psychologists, children, bruises, observations, costing numbers, and political targets into an order that allows for decisions to be reached. These processes of ordering are situated in the sense that they are effects of sociomaterial networks (Law, 1994). This means that each decision is not "new" but constructed in relation to each other, and to the particular situation at a given moment in time and space. What is relevant, then, is how the network relations produce variation. Inspired by theANT scholar John Law(1994) I approach the variations as different "modes of timing and spacing."Amode expresses patterns of organizing related to a particular orientation and a practical material situation. As Law(1994) writes, modes "tend to create and arrange things in one way rather than another" (p. 113). In this way, the modes of timing and spacing represent existing variations in the patterns of organizing "costing" and 
"caring" into decisions.

\section{EMPIRICAL SETTING AND METHODOLOGICAL CONSIDERATIONS}

As in all other public welfare areas, the Danish social service area has undergone a transformation toward more business- and market-like technologies of management throughout the previous 25 years. In 2007, pervasive political pressure to decrease costs and enhance efficiency resulted in a full decentralization of budget responsibility to the local governments. This means that each local government decides the level of appropriations for the various service areas, and which actions to take in case of overspending. The decentralization of budget responsibility came about at the same time as the Danish child protection system was undergoing a reform of its own. The purpose of this reform was to ensure that the needs of the child were the center of attention for all decisions about child protection services (National Board of Social Services, 2011), and these two requirements, decentralized budgets and the "child first" focus, had to work together and manifested by law in 2011 (Social Service Act, 2014). In practice, it means that Danish child protection departments are organized with a cost center, where statutory social workers order the services from private or public suppliers, a so-called purchaser-provider split (Siverbo, 2004). Throughout this paper, social workers are termed caseworkers to underscore that I investigate statutory social work, and not the part of social work where the provision of support is carried out.

The paper is based on a qualitative study of the role of cost information when caseworkers and managers decide which resources to allocate to individual children and their families. The study was undertaken in 2012 and 2013 in the child protection departments of three Danish local governments (LG1, LG2, and LG3). I chose to collect data at

Table 1: Methods and material

\begin{tabular}{|l|l|l|l|l|}
\hline Method & LG1 & LG2 & LG3 & Output \\
\hline Observations of decision meetings & 4 & 4 & 4 & App. 18 hours \\
\hline Semi-structured interviews w. caseworkers & 4 & 4 & 4 & Each 1-2 hours \\
\hline Semi-structured interviews w. managers & 3 & 3 & 3 & Each 1-2 hours \\
\hline Semi-structured interviews w. accountants & 1 & 1 & 1 & Each 1-2 hours \\
\hline Archival material & 31 & 41 & 24 & 96 docs \\
\hline
\end{tabular}

\section{LG= local government}

three different sites, because I was curious about whether or not patterns of decision making would differ according to accounting systems and the local environment. The local governments were selected for variance, representing different areas of Denmark and inhabitants of different socioeconomic backgrounds. They were also selected based on their public reputation as departments, which openly discuss and problematize the relationship between costing and caring practices. I found this to be important because it gave me an assurance that my interviewees would be open to talk to me about how they involved costing in their decisions and not merely express their opinions about costing practices. I carried out 12 observations of decision meetings to see and hear how choices were debated and how costing information was a part of it. The observations were used to generate situated face-to-face interviews with 12 statutory caseworkers and nine managers. With the observations as a common reference point, it was easy to talk about the practical processes leading up to, being a part of, and following the choices made. This also helped guide the conversations into being both descriptive of local practices and reflexive about controversies involved in the choice of services (Järvinen, 2005). In this way, opinions and value judgments on the role of accounting were given less space (Mahama \& Khalifa, 2017). Three face-to-face interviews were conducted with accountants. These were aimed at a more general description of the budget and cost control system in order to find out what was calculated, and how it connected with decisions to choose services. All interviews and observations were recorded and transcribed. These data were supplemented by archival material related to the decision processes such as budgets, guidelines, and legal documents. See Table 1 for an overview of the methods and material.

\subsection{Data analysis}

Throughout the process of collecting and analyzing data, I was guided by the ANT slogan to "follow the actor" (Latour, 2005, p. 12). My reading and organizing strategy was to look for actors, broadly understood, as any person or thing that does something to transform the choice and delimitation of social services. In this way, I stayed attuned to the practical work and how various elements-humans and non-humans-played a role in the decision-making processes. This was supplemented by an inductive coding process in NVivo, where descriptions of the budget and cost control systems of the three local governments were compared, and where links between accounting technologies and the criteria for 
choices and delimitations of services were identified (Coffey \& Atkinson, 1996; Kristiansen, 2010). This revealed that despite each of the local governments having a lump sum allocated on the budget for purchasing social services, the budget and costing systems were organized differently in each. For instance, budget targets were set by management in LG1 and LG3, whereas LG2 involved caseworkers in the analysis. LG1 and LG2 both had collective decision-making processes, whereas budgets of DKK 40,000 per child were devolved to the individual caseworker in LG1 (Schrøder, 2014). To my surprise, these differences were not reflected in the processes of choosing services. Decisions to invest in a support person, for instance, differed from processes of acute social support in the same way across all three local governments.

In a second step, I moved closer to the processes of choosing services by organizing the material concerning individual decisions according to how, when, and where costs showed up (Demant \& Ravn, 2017). I ended up with three clusters of material; one where information about costs was pushed to the future, one where costs were used as means to make services proceed, and one where costs seemed to be involved throughout the decision processes. The latter contained by far the most material. In reading the clusters separately, it was clear that each cluster contained distinctions between what qualified as criteria for choices and what did not. In the analysis, I present these clusters as modes of timing and spacing professional decisions. Each mode is illustrated by a situation that represents the patterns and varieties across the three modes. In the first situation, a young woman is in acute need of protection and the choice of service is made with reference to the severity of the past situation. In the second situation, a caseworker delimits the costs of a service by adding standard tariffs and passing on the result to the accounting department. In the third situation, the problems of a girl are turned into a case of prevention by estimating the future as problematic and costly.

\section{MODES OF TIMING AND SPACING PROFESSIONAL DECISIONS}

\subsection{Protecting}

This first decision concerns a 17-year-old girl, who has managed to escape an abusive boyfriend and reach the local authorities to ask for help. A caseworker recounted how the situation proceeded in an interview:

Caseworker: (...) The girl tells us everything and we go straight to the emergency department [of the hospital]. She is completely beaten up. In these extreme cases - she [the girl] needs to be protected in a crisis center for children and young people under 18 years of age - I don't consider costs at all. I don't ask the crisis center "how much does this cost? and so on." (...) It doesn't matter. This girl needs protection and she needs to get back to $x$-place as soon as possible, and the flight tickets were rather expensive...

I: Who do you talk to during this process?

Caseworker: There was nobody to talk to. So I made the decision. I could have called our consultants...But we know...it's not like...Our management is quite liberal. We don't get nervous, like "can we do this?", because when we're at the point where there are no other solutions, then, of course we are allowed [to grant acute help].

I: You get this case, and then? Could you explain to me practically, how is this process? At some point, something needs to be paid or how is it?

Caseworker: I call the father to get an oral consent for a placement. Even though it is a crisis center, it is still a placement. Due to the distance, I cannot get a written consent, so I get it by phone. And then I keep him updated along the way. And concerning the crisis center...she [the girl] is just lucky they had vacancies, otherwise she would have gone to an institution. Well, afterwards I write in the journal what is proposed as solutions, what is granted, and my assessment. And then I inform the home city.

In the first step of the decision making, the caseworker arranges the information by going "straight to the emergency department." In doing so, she not only tends to the medical needs of the girl, she also documents the situation of the girl as a case of protecting her from "domestic violence." In thisway, she makes it possible for an association to be made between the needs of the girl and a statutory solution to problems of domestic violence (Social Service Act, 2014,

$\S 109$ ). This foregrounds that the caseworker is not individually selectingwhich information to include or exclude, even though she claims to be making the decision on her own. The information that allows her to drawa distinction between protection or not, and the category of "domestic violence" is arranged with social legislation, the father of the girl, the 
emergency department, as well as the vacancies of the specific crisis center. These actors constitute the spacing of the decision, and when they are brought together, they make it possible to draw a distinction between an extreme case of violence that calls for acute action, and less extreme cases where action might be postponed. In this way, the acuteness of the situation results in a particularway of timing the information. The acuteness of the situation grants the caseworker a rare agency to act without permission, because there is simply no time to reach managers and consider possibilities. And there is no time to calculate the costs. In this way, the timing becomes a process of acting acutely rather than of narrowing down the choice of service from other possibilities. This means that the final distinction about the situation is already being produced through the first step of arranging the information. Accordingly, the acuteness of the situation becomes the main criterion for the choice and delimitation of service, and this is produced in a process of associating acuteness with protection against past problems.

With this spacing and timing, the information is arranged and associations are drawnin away that excludes the costs of the service from the process of choosing the service. The extreme characteristics of the situation make a clear case for a dichotomous relationship between costing and caring, where costing is resisted by the caring values of the social work profession (Kraus, 2012; Lapsley, 2008; Laughlin, 1996; Llewellyn, 1998a). The argument I want to make here, though, is the opposite. First, the situation illustrates how even an extreme case entails acts of attributing properties to the situation at stake, such as documented bruises, acuteness, consent, vacancies, legal paragraphs, and expenditure for flight tickets. This happens before distinctions can be drawn about the problem and its solution. Second, the young woman's situation foregrounds the point that the case indeed is "extreme" (as the caseworker calls it), yet costs do surface anyway as a relevant consideration.

\subsection{Maintaining}

The second situation concerns a process of delimiting how much to pay a biological mother for housing her child during the summer holidays. The situation takes place after the child protection department, the placement home, the child, and the mother have made a formal agreement to let the child move home for 1.5 months. In contrast to the situation with the 17-year-old girl, it illustrates a situation where the care for the individual child is left out of the mode of professional decision making.

The process of adding together the costs to cover a child's "daily necessities" for 1.5 months was described by a caseworker during an interview like this:

"So, I sit there and calculate in relation to KL's tariffs. I spend perhaps 20 minutes to make sure this girl will get her pocket money and the mother has money for food and clothes for a month and a half. (...). It costs this per day, how much for clothes-and pocket money per week and then I calculate the sum. Then I put the amount on an ordering ticket. It is quite cumbersome, where we copy from the old tickets the running costs and then copy the new ones into that. And then it is sent on to my consultant, who has the authorization to approve the order - I cannot do this myself, even though there is no doubt it needs to be paid - she sends it on to economy, where it is approved. She makes certain I have registered the correct paragraphs and the correct amount. Then I open the journal to make a journal note stating that it has been granted, and I actually also have to let the mother know it has been granted." (Caseworker)

In this process of arranging information, the choice of service is made beforehand and the costs are added together on the basis of tariffs and not the individual needs of the child. This turns it into a very different type of spacing than in the previous situation. The tariffs are listed in a document made by "KL" (the interest organization for Danish local governments). It includes 14 headlines stating a type of daily necessity, such as "food and accommodation" and "pocket money," and specified in accordance to the age of the child, the time period, and the number of children. For instance, pocket money for children between 3 and 10 years old is DKK 28 per week. Food and accommodation amount to DKK 173 per day for children who are more than 10 years old. At the top of the document, it is written in bold, underscored letters that the tariffs are only for guidance purposes. As the quote shows however, they are taken as facts. This means that the associations between the needs of the child and the costs allocated to meet those needs are produced by the list of tariffs. What the caseworker does is copy them into an ordering ticket. She does not consider whether the costs will meet the child's future needs.

The caseworker talks about the "copying" as a process that takes time. In this case, it took the caseworker about $20 \mathrm{~min}$ to add the costs for 1.5 months. The process of approval and allocation continued afterwards. The timing of the process is a matter of taking the steps in the right order, and about delimiting the costs by associating them with 
a certain time period. In this way, the timing is concerned with the present and with how to maintain distinctions that have already been drawn. So, this mode of timing and spacing is concerned with producing the new entity, an ordering ticket, which sums up prior arrangements and associations of information.

However, the production of a new entity is a process of drawing distinctions of its own: The production of an ordering ticket enables the calculation to leave the space of the caseworker and enter the space of an accountant. This, the caseworker explains, is a "cumbersome" process of several technical rather than cognitive steps. After copying, pasting and sending off for approval, the ordering ticket ends up in what she calls "economy." Through this process, "economy" is turned into a physical space, which she associates with the action of receiving the ordering ticket. What she is talking about is the accounting department, where accountants make sure the costs are related to the right accounts. Although the economic endeavor of the ordering ticket ends up in an accounting system, the caseworker's own decision process is not finished until she has informed the mother about the grant. The important point here is that the caseworker knows the spacing beforehand; she knows which associations to make and where to look for the criteria to set the limits of the costs. What is approved is not the decision to grant a particular amount of money, but rather that the registrations (the new entity) on the ordering ticket are based on the correct information-the correct legal paragraphs and the correct tariffs. This exposes that the distinction between costing and caring is constructed in a very material process of transforming decisions from being choices of how to care for needs into being "economy." Or, more particularly, into being a number that represents the correct costs. In this way, a simple adding-up of tariffs exemplifies the tenuous process of drawing distinctions between costing and caring.

\subsection{Preventing}

The third situation analyzed concerns Maria, a 13-year-old girl with mental as well as social problems. The analysis is based on a transcribed observation of a decision meeting, and a brief dialogue that follows the meeting. During the meeting, it is decided to allocate resources to a so-called "day-treatment." I first unfold how information is arranged and associated by describing the timing and spacing of information related to the decision. I then scrutinize more carefully how the distinctions are drawn as I analyze the dialogue following the choice of service.

The agenda of the meeting already arranges information by indicating which information might be relevant to include in the decision. Here, it is described that Maria has not attended school for 6 months, and that she threatens to kill herself if she is forced to go. Because of this, as well as information about her prior history, a decision has to be made about whether or not Maria should be offered a place in a specialized school. The meeting takes place in the office of the caseworkers' manager. The participants are Maria's caseworker, the manager of the caseworkers, the manager of a team of psychologists, and a psychologist. They are all seated around the same table. In the corner of the room, the secretary sits behind a computer screen at a desk. The spacing of the meeting, though, is not limited to the physical space of the meeting room and the material elements present. Distant elements, such as Maria, her parents, medical treatments, schools, budgets, legal rules, political targets, and guidelines, are also part of the meeting. The role of these elements are not given per se but take shape as they are drawn in or left out of the meeting. Most important is a psychological assessment that represents the life of Maria at present and a concern about the future. As the psychologist presents her assessment, she refers to the scores in the report. She concludes that Maria's symptoms are similar to those of a new diagnosis, about which evidence shows that there is a $60 \%$ risk that she will develop serious psychiatric disorders in adult life if she is not treated early. The psychologist describes Maria's situation by drawing on impressions, a psychological scoring system, and scientific evidence about the probable condition of the girl. This allows for the rather vague observations that Maria is "not doing well socially" (psychologist) and that "Maria might stumble again" (caseworker) to be associated with a problematic future. In this process of arranging information and making associations between past, present, and future, Maria is transformed from being a distant person that they have assumptions about into being a person with a set of properties that they can make predictions about.

This involves associating information about Maria with a situation of preventing future problems from escalating. In doing so, present problems are associated with a distant and problematic future that has to be acted upon now, rather than later, by treating her situation as a case of mental illness. This is a distinction between mental and social health problems. Although the former might be prevented by treatment, it is more ambiguous how a social problem develops and might be prevented. By drawing these distinctions, the needs of Maria are associated with so-called "day treatment," which is one of nine types of interventions listed in the Social Service Act. This particular service includes both a specialized school and a specialized treatment. What started out as a school related social problem is now established as an escalating psychiatric disorder. The meeting participants delimit the day-treatment by connecting a privately run and specialized out-patient treatment with a place in a specialized local public school. In doing so, they fulfill 
a political requirement to keep children in their local environment and they rule out the parents' wishes for a geographically more distant private school.

After the choice of service has been typed in by the secretary, and as the caseworker is about to leave the meeting room, the caseworker suggests making a distinction based on the costs of the choice. The following is a transcription of the brief dialogue:

Caseworker: But the question is: Which is more expensive? It might be...now we're just thinking aloud where no parents can hear us - the question is, if there is a price difference and if it is relevant, or if they [the parents] should be offered to choose a combined school and treatment solution rather than the outpatient treatment [and the local school].

Manager: In my view that is not an option. Because, if we have the presumption that the local school can meet her [Maria's] needs, then that's it. (...). The combined solution cannot match the outpatient treatment.

"Which is more expensive?" the caseworker asks. The comparison refers to the monthly costs of buying both special school and outpatient treatment, or the monthly costs of buying the combined and more standard solution from the private supplier, which the parents preferred. In making the comparison, the caseworker suggests that a price difference between the two alternatives might turn out to be a criterion for taking the wishes of the parents into account. Through this, she associates the wishes of the parents with the possibility of paying a cheaper price. The manager dismisses the association as she points out that by choosing the specialized outpatient treatment they will better match Maria's needs than if they choose the more standard, but possibly cheaper, combined solution. This exposes that the need for treatment is produced as the main criterion. It also illustrates that information is arranged by moving places and people in and out of the decision making and that different associations between costs and needs are tested and finally established as one way of predicting their relationship.

The quoted segment also exposes that associations between costs and solutions cannot be made in all places and at all times. As the caseworker expresses it, they are "just thinking aloud-where no parents can hear" them. As if she is saying that it is easier to talk about the costs when the parents are not present. More specifically, the quote exposes a specific characteristic of this mode of timing and spacing. The distinction drawn between the parents and the costs is practical in the sense that it takes place after a choice has been made and in a way that prevents the conversation from being part of the written decision. More importantly, though, it underscores that knowledge about the specific costs of services does not help them make distinctions relevant for the choice of service. However, after the meeting, when only the two managers are left in the room, the caseworkers' manager lets out a deep sigh, and says: "It has actually been decided politically that expenditure for day treatment should decrease. But compared to last year, they are certainly

Table 2: The characteristics of the modes of protecting, maintaining and preventing

\begin{tabular}{|l|l|l|l|}
\hline Course of action & $\begin{array}{l}\text { Mode of Protecting } \\
\text { from problems }\end{array}$ & Mode of Maintaining & Mode of Preventing \\
\hline Consequence & Protection from the past & Maintaining services & Preventing future problems \\
\hline Associations & $\begin{array}{l}\text { Acuteness = protection } \\
\text { Bruises=legal paragraph }\end{array}$ & $\begin{array}{l}\text { Age=tariff } \\
\text { Duration=tariff }\end{array}$ & $\begin{array}{l}\text { Mental health problem=day treatment } \\
\text { Present state=future problems } \\
\text { Local solution=political goal }\end{array}$ \\
\hline $\begin{array}{l}\text { Distinctions } \\
\text { related to costs }\end{array}$ & Expensive / not expensive & Age / duration & $\begin{array}{l}\text { Budget target / political goal } \\
\text { Parents / costs } \\
\text { Expensive / not expensive }\end{array}$ \\
\hline $\begin{array}{l}\text { Distinctions } \\
\text { related to needs }\end{array}$ & $\begin{array}{l}\text { Extreme / not extreme } \\
\text { Past / present }\end{array}$ & None & $\begin{array}{l}\text { Documented / not documented } \\
\text { Observations / psychological assessment } \\
\text { Social / mental } \\
\text { Present / future } \\
\text { Standard / special }\end{array}$ \\
\hline Roles of costs & Not relevant & Decisive & Ambiguous \\
\hline
\end{tabular}




\begin{tabular}{|l|l|l|l|}
\hline Roles of needs & Decisive & Not relevant & Ambiguous \\
\hline
\end{tabular}

Even though the manager is well aware of the problematic budget implications of the choice, this has not been transformed into a criterion for the choice of service. Accordingly, this exemplifies that information of the budget target is arranged in a way that excludes it from the decision making.

Does this illustrate that costs are not a part of this mode of timing and spacing? No. It illustrates that it is an achievement in itself that the mentioning of costs was left out of the decision. It requires that they put as much information as possible under scrutiny, and leave the conversation about costs until after the secretary has finished writing up the minutes. As such, it is neither "costing" nor "caring" that limits and allows particular choices to be made, but the (many) tools and elements that make the best possible prediction about the future. I have analyzed three different situations that each amounted to a specific way of timing and spacing the choice and delimitation of services: (1) protecting, (2) maintaining, and (3) preventing. This is summarized in Table 2.

\section{DISCUSSION: THE PRACTICAL EFFORTS OF RELATING COSTING AND CARING}

In this section, I discuss how costing and caring come to be related by comparing the three modes of timing and spacing. This shifts the attention away from the individual decisions, and toward the characteristics and patterns of the decision processes that took place in the three child protection departments.

\subsection{Timing}

As an action, timing works in two distinct ways. First, timing is away of organizing the steps of the decision into a certain order. In the mode of maintaining, the steps of the process are stable, in the sense that what needs to be done is preplanned. The caseworker, for instance, cannot grant the mother any money before the sum of her calculation has made it to "economy." In the mode of protecting, the timing of steps is activated by the situation of the young woman. Timing is reactive. This is why the cost implications are deemed to "not matter." In both of these modes, the timing results in a distinction to be drawn between needs and costs. Where needs are left out from the mode of maintaining, costs are left out from the mode of protecting. It could seem like caseworkers prioritize the one to the detriment of the other (Bracci \& Llewellyn 2012; Kraus \& Lindholm, 2010). However, it is not the caseworkers' priorities that make the relationship between costing and caring differ but the timing of the steps in the process of reaching a decision. In the mode of preventing, the timing of steps takes on a third constellation. Here, the steps are bundled together in one meeting, where elements are detached and attached to the situation of the girl.

Table 3: The modes of timing

\begin{tabular}{|c|c|c|c|}
\hline & Mode of Protecting & Mode of Maintaining & Mode of Preventing \\
\hline Timing the steps to take & Reactive & Pre-planned & Bundled \\
\hline $\begin{array}{l}\text { Timing the orientation of the } \\
\text { decision }\end{array}$ & $\leftarrow_{\text {Past and present }}$ & Present & $\stackrel{\text { Past, present and future }}{\longrightarrow}$ \\
\hline Time as linear & Scarce & Norm & Asset \\
\hline
\end{tabular}

Second, timing is a consequence of how information about the situation at stake has been mobilized. In the mode of protecting, information was organized in a past and a present, which made it possible to draw associations between past problems and acute protection. In the mode of maintaining, the information was about the present, and amounted to associations between age, duration, and specific tariffs. And in the mode of preventing, the information was organized in a past, present, and future, which allowed for associations to be drawn between the present state of problems and a problematic future. This let three distinct timings emerge, each with a course of action: removing, allocating, and planning, which were estimated to protect, maintain, and prevent. Also, as linear temporality, time had different roles to play: When "protecting" time was scarce, when "maintaining" time was a norm and when "preventing" time was an asset. The three modes of timing are summarized in Table 3.

\subsection{Spacing}


Timing is closely related to the spacing of information, tools, and other humans and nonhumans taking part in the decision. Spacing is the action of moving elements around, detaching and attaching them to the situation at stake, associating Them with each other, and finally summing up the result of the movements in one place. Protecting the young woman was a process of associating the bruises on a body with a legal paragraph by moving the bruises to the ER, where they were documented and classified as "domestic violence." It also involved telephones, airplanes, and the physical distance between the present place of the young woman, and a home away from her boyfriend. Most specifically, it involved the vacancies in the one crisis center with rooms for underaged women. Although these places are spread out in physical space, they all refer back to the young woman. And even though the costs are not included as a criterion for the choice of service, they are still taken into account. Table 1 illustrates this with a drawing of five dots, enclosed by a circle that excludes one dot. The aim of this is to visualize a stable spacing with one center, and where only the costs, and possibly a few other elements, are left out for the time being.

The spacing of preventing took on a different shape. Here, a meeting made it possible for the wide reaching and heterogeneous elements to be drawn together. In this way, the spacing was a process of moving information in and out of the discussion rather than moving persons and things from one place to another. The psychological assessment made it possible to predict the development of a psychiatric disorder in the future. Through this, it made the treatment needs of the girl the main reference point of the spacing. The reference point would possibly have been different if there had not been a psychological assessment. In this way, the mode of preventing represents decision making as a process, where the needs of the clients are constructed while choosing and delimiting services. This is in opposition to the health care area, where the choice of cure is expected to be made from the known disease and medical needs (cf. Llewellyn \& Northcott 2005; Sjögren \& Fernler, 2019). The more ambiguous and nonlinear process is illustrated in Table 4 as 15 dots are kept together by an irregular shape that excludes seven dots.

Timing and spacing arranges the processes so that decisions can be reached. In the mode of protecting, there was no time to set up a meeting, whereas in the mode of preventing, the choice of service was arranged at a meeting. When services have been chosen and delimited, the result is brought together in one place. Such places are, for instance, the

Table 4: The modes of spacing

\begin{tabular}{|l|l|l|}
\hline $\begin{array}{l}\text { Spacing the orientation } \\
\text { of the decision }\end{array}$ & Mode of Protecting & Mode of Maintaining \\
\hline The spacing of costs & Postponed & Stable \\
\hline The spacing of needs & $\begin{array}{l}\text { Moving the child } \\
\text { around }\end{array}$ & $\begin{array}{l}\text { Not relevant } \\
\text { needs around }\end{array}$ \\
\hline
\end{tabular}

minutes from the meeting regarding prevention, and the journal note in the filing system of the caseworker who chose to protect the young woman from past actions. In the mode of maintaining, the ordering ticket was a clear example of how a place sums up information and allows for a result to circulate to other places. In this case, the service could not be granted before the ordering ticket was circulated to the accounting system. The spacing of this process only involved numbers and was concerned with moving money from one place to another. In Table 1, this is illustrated with only two dots surrounded by a regular circle, signaling that in this mode the needs of the children are not expected to be included.

\subsection{Costing}

Now I turn to the question that motivates the paper: How is cost information involved in professional decisions to allocate resources to individual clients? I have defined three modes of timing and spacing, in which costs were only calculated in the mode of maintaining. In this mode, costs are taken as a given and the needs of the child are disregarded as an issue that was taken care of at another point in time. This observation is central, because it highlights how the 
different modes relate to each other. The individual caseworker does not work within one of the modes, but weaves in and out of them, sometimes planning for the future, sometimes coordinating costs, and sometimes protecting against past actions. This not only explains why it is difficult to calculate a cost to guide decisions a priori. It also explains why it is not possible to draw conclusions about the role of costs from one mode, and not the others. The PSAR debates on the role of costs in professional decision making are mostly concerned with whether or not cost information is used in decision making (Bracci\&Llewellyn, 2012; Carlsson-Wall et al., 2016; Jacobs, 2005; Jönsson\&Solli, 1993; Kraus, 2012; Kurunmäki, 2004; Kurunmäki et al., 2003; Laughlin, 1996; Llewellyn, 1993, 1998a; Llewellyn \& Northcott, 2005). Kurunmäki (2004), for instance, provides evidence that cost information is created and used by the medical professionals of their study as a means to follow and compare expenditure for operations between departments and over time. Jacobs (2005) questions this by illustrating that the use of cost information is delegated to subgroups rather than an entire profession. This "either/or" perspective is also present in the early studies of accounting in social work settings by Jönssen and Solli (1993), Llewellyn (1993, 1998a), and Laughlin (1996) and continues to dominate the research in more recent studies (Bracci\&Llewellyn, 2012; Carlsson-Wall et al., 2016; Kraus, 2012). However, even though these studies of accounting in social work settings take the "either/or" perspective as their starting point, they end up conveying the roles and uses of cost information as ambiguous. As a contrast to this ambiguity, the studies of costing in health care setting more generally conclude that costs are either used or not. Llewellyn and Northcott (2005) is an illustrative example of how cost-based categories are used to guide the choice of cure, and Kurunmäki et al. (2003) also very specifically categorize cost information as either an integrated element of decision making or a shield to protect medical values and ethics.

In this paper, I suggest that it is not possible to come to a final conclusion about whether or not cost information is part of a decision or not. Drawing a conclusion from the mode of protecting would suggest that costs are not involved in decision making, whereas drawing it from the mode of maintaining would suggest they are-even to the degree that they distort the purpose of the decision making. However, the modes of decision making do not emerge on their own, but in relation to each other and the setting they are a part of (cf. Hopwood, 1983 for a similar argument). Accordingly, entanglement and ambiguity are much more common than a clear cut "use or not." To this end, studies of professional decisions in allocating resources to individual clients and patients provide a unique access to how accounting practices are shaped in professional settings. The paper by Bracci and Llewellyn (2012) illustrates this by revealing that accounting practices differ according to whether client problems are intractable. Frandsen (2010) shows that accounting is a process of continuously translating between numbers and diseases rather than a practice consisting of predetermined tools. And Sjögren and Fernler (2019) suggest that costs are translated into, and measured as, time units. My analysis adds to these papers by suggesting a fourth possibility that costing and caring practices are continuously constructed in at least three different ways, and that different relationships between costing and caring can be present together in the same setting.

Within PSAR, scholars inspired by new institutional theory have argued that conflicting and multiple logics are navigated into co-existing processes of decision making (Pettersen \& Solstad, 2014; Rautiainen \& Järvenpää, 2012). In doing so, they assume the distinction between costing and caring to be predetermined by logics belonging to specific professions or levels of the institution. In this way, the question of where such logics come from and how they are made into distinct ideas about future courses of action becomes less relevant. This is why their emphasis is different from the present paper. In this paper, the practical work of arranging, associating, and coming to a conclusion about future courses of action are emphasized, and through this it is conveyed that logics are not predetermined nor do they belong to a specific group and place. To the contrary, they vary according to the different modes of timing and spacing. The mode of preventing reveals that it takes a lot of practical work to separate costing and caring from each other, because knowing the cost implications of choices is just as ambiguous as knowing the specific needs of a child. In themode ofmaintaining, the costs were not ambiguous, but the process of producing them as a new entity revealed that the needs of the child and the costs of services were separated from each other in a tenuous and very material process.

\section{CONCLUSION}

In this paper, I have analyzed and described the relationships between cost information and professional decision making through an inside-out investigation of the practical efforts to reach decisions in three Danish child protection departments. Inspired by the symmetrical approach of ANT, the ambition of this paper was to open up the notions of "costing" and "caring" and to analyze how they come to relate to each other in processes of reaching decisions about individual children and families. Instead of assuming a distinction between the two, I analyzed how, when, and where the distinctions are drawn. I employed Callon and Muniesa's (2005) broad and processual notion of calculation in an analysis 
of professional decisions as modes of timing and spacing (Law, 1994). I unfolded how three modes of professional decisions arose next to each other as the result of the timing and spacing of information. In each of the modes, distinctions were drawn in a particular way that constituted the relationship between costs and needs differently. Rather than costing being translated into caring and/or the other way around, I revealed that distinctions between costing and caring were continuously produced as a result of the practical arrangement of the particular mode of decision making.

This suggests that costing and caring not only vary according to the situation at stake (Bracci \& Llewellyn, 2012), the context (Kraus \& Lindholm, 2010; Llewellyn, 1998b), a certain ethos (Lapsley, 2008; Laughlin, 1996), or discourse (Carlsson-Wall et al., 2016; Jönsson \& Solli, 1993; Llewellyn, 1998a), but also according to practical and calculative capacities. When it is not possible to decide on a solution before distinctions about the situation have been drawn, then it is the capacities for timing and spacing that make decisions possible. Accordingly, the paper suggests that professional decision making is more about timing and spacing information than it is about choosing between, for instance, quantitative and qualitative forms of knowledge or between costs and needs. This means that the agency for decision making is spread out in a network of sociomaterial elements rather than being centered within a profession. As the timings and spacings vary, so do the connections between costs and needs. When observed from the outside, these variances might make professional decision-making processes look like a mess of entangled individual choices. Yet a closer look at the decisions in this analysis shows that the choices of services are the result of meticulously orchestrated ordering processes.

The paper also contributes to PSAR with an elaboration of welfare professional work by juxtaposing the fields of curing and caring. In curing work, unknown and changeable client characteristics are an exception that makes action more expensive (Llewellyn \& Northcott, 2005) or possibly makes action stop (Fernler and Sjögren, 2019). In caring work, unknown and changeable client characteristics are the rule rather than the exception (Bracci \& Llewellyn, 2012). This explains the ambiguous role of cost information as present, but not talked about. While individual needs are constructed as stable for the purpose of choosing a course of action, it is difficult for a standard cost category or a budget limit to guide decisions. Instead, a lot of effort goes into separating costing from caring. In this way, the paper surprisingly indicates that hybridity involves the work of separating costing and caring. This further implies that caring work is a fruitful site for future investigations into what it means to be "hybrid" (Miller, Kurunmäki, \& O'Leary, 2008). Such investigations would gain from an ethnographic approach.

\section{ACKNOWLEDGMENTS}

The financial support from the Danish National Board of Social Services and the Independent Research Fund Denmark Research grant 1329-00137B is greatly acknowledged. The paper has benefited from inspiring discussions with Jan Mouritsen, Lise Justesen, Dane Pflueger, and the participants at paper seminars on Stockholm Business School and at the Department of Social Work at the Metropolitan University College. Also the constructive comments and suggestions from the two reviewers have been a great help in the development of the paper.

\section{References}

Abernethy, M. A., Chua, W. F., Grafton, J., \& Mahama, H. (2007). Accounting and control in health care: Behavioural, organisational, sociological and critical perspectives. In C. S. Chapman, A. G. Hopwood, \& M. D. Shields (Eds.), Handbook of management accounting research (pp. 805-829). Amsterdam, The Netherlands: Elsevier Ltd. https://doi.org/10.1016/S1751-3243(06)02014-1

Abernethy, M. A., \& Stoelwinder, J. U. (1995). The role of professional control in the management of complex organizations. Accounting, Oranizations and Society, 20(1), 1-17. https://doi.org/10.1016/0361-3682(94)E0017-O Arnaboldi, M., Lapsley, I., \& Steccolini, I. (2015). Performance management in the public sector: The ultimate challenge. International Journal of Public Sector Management, 31(1), 1-22. https://doi.org/10.1111/faam.12049

Baxter, J.,\&Chua,W. F. (2003). Alternative management accounting research-Whence and whither. Accounitng, Organizations and Society, 28(2-3), 97-126. https://doi.org/10.1016/S0361-3682(02)00022-3

Bracci, E. (2014).Accountability and governance in social care: The impact of personalisation. Qualitative Research in Accounting \& Management, 11(2), 111-128. https://doi.org/10.1108/QRAM-04-2014-0033 
Bracci, E., \& Llewellyn, S. (2012). Accounting and accountability in an Italian social care provider-Contrasting people-changing with peopl-processing approaches. Accounting, Auditing \& Accountability Journal, 25(5), 806-834. https://doi.org/10.1108/09513571211234268

Briers, M., \& Chua, W. F. (2001). The role of actor-networks and boundary objects in management accounting change: A field study of an implementation of activity-based costing. Accounting, Organizations and Society, 26(3), $237-269$. https://doi.org/10.1016/S0361-3682(00)00029-5

Callon, M., \& Muniesa, F. (2005). Peripheral vision: Economic markets as calculative collective devices. Organization Studies, 26(8), 1229-1250. https://doi.org/10.1177/0170840605056393

Carlsson-Wall, M., Kraus, K., Lund, M., \& Sjögren, E. (2016). "Accounting talk" through metaphorical representations: Change agents and organisational change in home-based elderly care. European Accounting Review, 25(2), 215-243. https://doi.org/10.1080/09638180.2014.992921

Chapman, C., Kern, A., \& Laguecir, A. (2014). Costing practices in healthcare. Accounting Horizons, 28(2), 353-364. https://doi.org/10.2308/acch-50713

Coffey, A., \& Atkinson, P. (1996). Making sense of qualitative data. Thousand Oaks, CA: Sage Publications.

Covaleski, M. A., Dirsmith, M. W., \& Michelman, J. E. (1993). An institutional theory perspective on the DRG frameworks, case-mix accounting systems and health care organizations. Accounting, Organizations and Society, 18(I), 65-80. https://doi.org/10.1016/0361-3682(93)90025-2

Czarniawska, B. (2004). On time, space, and action nets. Organization, 11(6), 773-791. https://doi.org/10.1177/ 1350508404047251

Czarniawska, B. (2017). Organization studies as symmetrical ethnology. Journal of Organizational Ethnography, 6(1), 2-10. https://doi.org/10.1108/JOE-12-2016-0023

Demant, J., \& Ravn, S. (2017). Aktør-netværskteori og kvalitative interviews. In M. Järvinen \& N. Mik-Meyer (Eds.), Kvalitativ analyse - syv traditioner (pp. 389-412). København: Hans Reitzels Forlag.

Frandsen, A. (2010). The role of disciplining/translating accounting practices in patient-centred care. International Journal of Public Sector Management, 23(4), 381-391. https://doi.org/10.1108/09513551011047279

Glennerster, H. (1994). New challenges formanegement accounting: Issues in health and social services. Financial Accountability \& Management, 10(2), 131-141. https://doi.org/10.1111/j.1468-0408.1994.tb00384.x

Hood, C. (1991). A public management for all seasons? Public Administration, 69(1), 3-19. https://doi.org/10.1111/ j.1467-9299.1991.tb00779.x

Hopwood,A.G. (1983).On trying to study accounting in the contexts in which it operates. Accounting, Organizations and Society, 8(2-3), 287-305. https://doi.org/10.1016/0361-3682(83)90035-1

Jacobs, K. (2005). Hybridisation or polarisation: Doctors and accounting in the UK, Germany and Italy. Financial Accountability \& Management, 21(2), 135-162. https://doi.org/10.1111/j.1468-0408.2005.00213.x

Järvinen, M. (2005). Interview i en interaktionistisk begrebsramme. In M. Järvinen \& N. Nik-Meyer (Eds.), Kvalitative metoder $i$ et interaktionistisk perspektiv—Interview, observationer og dokumenter (1st ed., pp. 27-49). København: Hans Reitzels Forlag.

Johansson, T., \& Siverbo, S. (2014). The appropriateness of tight budget control in public sector organizations facing budget turbulence. Management Accounting Research, 25(4), 271-283. https://doi.org/10.1016/j.mar.2014.04.001

Jones, G., McLean, C., \& Quattrone, P. (2004). Spacing and timing. Organization, 11(6), 723-741. https://doi.org/10.1177/ 
Jönsson, S., \& Solli, R. (1993). "Accounting talk" in a caring setting. Management Accounting Research, 4(4), 301-320. https://doi.org/10.1006/mare.1993.1017

Junne, J., \& Huber, C. (2014). The risk of users' choice: exploring the case of direct payments in German social care. Health, Risk \& Society, 16(7-8), 631-648. https://doi.org/10.1080/13698575.2014.973836

Justesen, L., \&Mouritsen, J. (2011). Effects of actor-network theory in accounting research. Accounting, Auditing \& Accountability Journal, 24(2), 161-193. https://doi.org/doi.org/10.1108/09513571111100672

Kastberg, G., \& Siverbo, S. (2016). The role of management accounting and control in making professional organizations horizontal. Accounting, Auditing \& Accountability Journal, 29(3), 428-451. https://doi.org/10.1108/AAAJ-03-2014-1632

Kirk, K., \& Mouritsen, J. (1996). Spaces of accountability: Systems of accountability in a multinational firm. In R. Munro \& J. Mouritsen (Eds.), Accountability: Power, ethos and the technologies ofmanaging (pp. 245-260). Hampshire: Cengage Learning.

Kraus, K. (2012). Heterogeneous accountingisation: Accounting and inter-organisational cooperation in home care services. Accounting, Auditing \& Accountability Journal, 25(7), 1080-1112. https://doi.org/10.1108/09513571211263202

Kraus, K., \& Lindholm, C. (2010). Accounting in inter-organisational relationships within the public sector. In $\mathrm{H}$. Håkansson, K. Kraus, \& J. Lind (Eds.), Accounting in networks (pp. 113-148). New York, NY: Routledge.

Kristiansen, S. (2010). Kvalitative analysredskaber. In L. Tanggaard \& S. Brinkmann (Eds.), Kvalitative Metoder-En grundbog (1st ed., pp. 447-463). København: Hans Reitzels Forlag.

Kurunmäki, L. (1999). Making an accounting entity : the case of the hospital in Finnish health care reforms. The European Accounting Review, 8(2), 219-237. https://doi.org/10.1080/096381899336005

Kurunmäki, L. (2004). A hybrid profession-The acquisition of management accounting expertise by medical professionals. Accounting, Organizations and Society, 29(3-4), 327-347. https://doi.org/10.1016/S0361-3682(02)00069-7

Kurunmäki, L. (2009). Management accounting, economic reasoning and the new public management reforms. In C. S. Chapman, A. G. Hopwood, \& M. D. Shields (Eds.), Handbook of management accounting research (Vol. 3, pp. 1371-1383). Amsterdam, The Netherlands: Elsevier. https://doi.org/10.1016/S1751-3243(07)03009-X

Kurunmäki, L., Lapsley, I., \& Melia, K. (2003). Accountingization v. legitimation: A comparative study of the use of accounting information in intensive care. Management Accounting Research, 14(2), 112-139.

https://doi.org/10.1016/S1044-5005(03)00019-2

Lægreid, P., \& Neby, S. (2016).Gaming, accountability and trust: DRGs and activity-based funding inNorway. Financial Accountability \& Management, 32(1), 57-79. https://doi.org/10.1111/faam.12080

Latour, B. (2005). Reassembling the social.Oxford, UK: Oxford University Press.

Lapsley, I. (2008). The NPM agenda: Back to the future. Financial Accountability \& Management, 24(1), 77-97.

https://doi.org/10.1111/j.1468-0408.2008.00444.x

Laughlin, R. (1996). Principals and higher principals: Accounting for accountability in the caring professions. In R. Munro \& J. Mouritsen (Eds.), Accountability-Power, ethos \& the technologies of managing (1st ed., pp. 225-244). Hampshire: Cengage Learning.

Law, J. (1994). Organizing modernity. Oxford: Blackwell. 
Llewellyn, S. (1993). Linking costs with quality in health and social care: New challenges for management accounting. Financial Accountability \& Management, 9(3), 177-194. https://doi.org/10.1111/j.1468-0408.1993.tb00372.x

Llewellyn, S. (1998a). Boundary work: Costing and caring in the social services. Accounting, Organization and Society, 23(1), 23-47. https://doi.org/10.1016/S0361-3682(96)00036-0

Llewellyn, S. (1998b). Pushing budgets down the line: Ascribing financial responsibility in the UK social services. Accounting; Auditing and Accountability Journal, 11(3), 292-308. https://doi.org/10.1108/09513579810224518

Llewellyn, S., \& Northcott, D. (2005). The average hospital. Accounting, Organizations and Society, 30(6), 555-583. https://doi.org/10.1016/j.aos.2004.05.005

Llewellyn, S., \& Saunders, I. (1998). Tracking resource use in a welfare organization: Needs, costs and co-production. Financial Accountability \& Management, 14(2), 39-56. https://doi.org/10.1111/1468-0408.00049

Mahama, H., \& Khalifa, R. (2017). Field Interviews-Process and analysis. In Z. Hoque, L. D. Parker, M. A. Covaleski, \& K. Haynes (Eds.), The Routledge companion to qualitative accounting research methods (pp. 321-338). New York, NY: Routledge.

Mannion, R., \& Smith, P. (1997).How purchasing decisions are made in the mixed economy of community care. Financial Accountability \& Management, 13(3), 243-260. https://doi.org/10.1111/1468-0408.00036

Miller, P., Kurunmäki, L., \& O'Leary, T. (2008). Accounting, hybrids and the management of risk. Accounting, Organizations and Society, 33(7-8), 942-967. https://doi.org/10.1016/j.aos.2007.02.005

Modell, S., \& Lee, A. (2001). Decentralization and reliance on the controllability principle in the public sector. Financial Accountability \& Management, 17(3), 191-218. https://doi.org/10.1111/1468-0408.00128

Mouritsen, J.,Mahama, H.,\&Chua,W. F. (2010).Actor-network theory and the study of inter-organisational network relations. In H. Håkansson, K. Kraus, \& J. Lind (Eds.), Accounting in networks (pp. 293-313). New York, NY: Routledge. National Board of Social Services. (2011). Håndbog om barnets reform (2nd ed.). Odense, Denmark: National Board of Social Services. Retrieved from https://socialstyrelsen.dk/udgivelser/handbog-om-barnets-reform

Nyland,K.,\&Pettersen, I. J. (2004). The control gap: The role of budgets, accounting information and (non-) decisions in hospital settings. Financial Accountability \& Management, 20(1), 0267-4424. https://doi.org/10.1111/j.1468$\underline{0408.2004 .00187 . x}$

Pettersen, I. J. (1995). Budgetary control of hospitals-Ritual rhetoric and rationalized myths? Financial Accountability \& Management, 11(3), 207-221. https://doi.org/10.1111/j.1468-0408.1995.tb00405.x

Pettersen, I. J., \& Solstad, E. (2014). Managerialism and profession-based logic: The use of accounting information in changing hospitals. Financial Accountability \& Management, 30(4), 363-382. https://doi.org/10.1111/faam.12043

Preston, A. M., Cooper, D. J., \& Coombs, R. W. (1992). Fabricating budgets: A study of the production of management budgeting in the national health service. Accounting, Organizations and Society, 17(6), 561-593.

https://doi.org/10.1016/0361-3682(92)90014-J

Quattrone, P., \& Hopper, T. (2005). A 'time-space odyssey': Management control systems in two multinational organisations. Accounting, Organizations and Society, 30(7-8), 735-764. https://doi.org/10.1016/j.aos.2003.10.006

Rautiainen, A., \& Järvenpää, M. (2012). Institutional logics and responses to performance measurement systems. Financial Accountability \& Management, 18(2), 164-188. https://doi.org/10.1111/j.1468-0408.2012.00541.x

Statistics Denmark. (2018). Esspros1. [Data file. Social expenditure by type of intervention and time]. Retrieved from http://www.statistikbanken.dk/esspros1. 
Schrøder, I. M. (2014). Budgetblikket i socialt arbejde med udsatte børn og unge. Frederiksberg: Professionshøjskolen Metropol, Institut for Socialt Arbejde.

Social Service Act. (2014). LBK no. 254 of 20/03/2014. Retrieved from https://www.retsinformation.dk/forms/R0710.aspx? $\mathrm{id}=161883$

Siverbo, S. (2004). The purchaser-provider split in principle and practice: Experiences from Sweden. Financial Accountability \& Management, 20(4), 401-421. https://doi.org/10.1111/j.1468-0408.2004.00201.x

Sjögren, E., \& Fernler, K. (2019). Accounting and professional work in established NPM settings. Accounting, Auditing \& Accountability Journal, 32, 897-922.

Van Helden, G. J. (2005). Researching public sector transformation: The role of management accounting. Financial Accountability \& Management, 21(1), 99-115. https://doi.org/10.1111/j.0267-4424.2005.00211.x

Vikkelsøe, S. (2007). In between curing and counting: Performative effects of experiments with heathcare information infrastructure. Financial Accountability \& Management, 23(3), 269-289. https://doi.org/10.1111/j.1468-0408.2007.00429.x

Wällstedt, N. (2015). Managing multiplicity—On control, care and the individual. Stockholm: Business School. 